\title{
The Politics Behind Consensus: Tracing the Role of the Commission within the European Employment Strategy
}

\section{Isabelle Deganis}

\section{Introduction}

By virtue of its favourable positioning within European Union (EU) decision-making processes, its vast array of constitutional resources, and its ability to articulate vision and direction, the European Commission stands at the heart of the EU system of governance (Nugent 2000). Accordingly, based on the central assumption - widely held in the field of European studies - that the Commission is a competence-maximizing rational actor, whose primary organizational goals are to expand the scope of Community competence and increase its own standing within the policy process (Majone 1991, Peters 1992, Cram 1993, Pollack 1994), scholarly debate has long been concerned with evaluating the extent to which the Commission independently impacts on EU decision-making. To date, commentators in this field have systematically sought to investigate and theorise the Commission's role within the classic "Community method" (CCM), which has been its exclusive domain of action for the past four decades (Scott and Trubek 2002). However, this academic bias appears more and more untenable in view of the growing importance of new modes of governance - of which the Open Method of Coordination (OMC) is the most prominent example - within the political landscape of the EU. Accordingly, certain fundamental questions arise. How has the European Commission sought to adapt to these new modes of governance? What means has it employed to gain influence within such novel institutional frameworks?

In order to shed some light on this new field of inquiry, this paper sets out to examine the role of the Commission within one particular strand of the OMC, namely the European Employment Strategy (EES), through the lens of the advocacy coalition framework (ACF) (Sabatier and JenkinsSmith 1993). ${ }^{1}$ The argument set forth in this article is that although largely intent on mobilizing consensus between national governments - or more precisely between two principal advocacy coalitions - the Commission has purposefully sought to increase its standing within the European Employment Strategy by (1) taking advantage of its formal powers and responsibilities, most notably with regard to its special relationship with the Secretariat of the Employment Committee, and (2) by establishing and conscientiously upholding a fictitious sole right of initiative within the field of employment policy. ${ }^{2}$

The article proceeds in four steps. Following an overview of the early academic work in the field of the EES, laying particular emphasis on the role of the Commission therein (section 2), section 3 details the original institutional design of the EES. Section 4 outlines the central tenets 
of the advocacy coalition framework. Section 5 presents the results of this empirical research. Finally, a concluding section provides a brief summary of this study's findings and expounds on its implications for future research.

\section{Mapping the early academic literature in the field of the EES}

To date, the growing body of literature surrounding the EES can be split into two main categories. First, particular emphasis has been placed on examining the EES - and more generally the $O M C$ - as an ideal-type. Numerous accounts of the institutional set-up of the EES have led to the formulation of an extensive list of expectations about its democratic qualities and potential in terms of governance, most notably with regards to its capacity to promote experimental learning and deliberative problem-solving. ${ }^{3}$ Second, preliminary empirical work in this field pertains to the nascent debate on Europeanization, since a fundamental concern among commentators has been to evaluate the impact of the EES on national politics, policies and polities. ${ }^{4}$ Thus, a cursory overview of this blossoming academic literature brings to light both the principally normative quality of the debate and the relatively tentative conclusions of early empirical research in this field (Zeitlin 2005: 447-503).

In view of the importance given in the field of European studies to the role of the Commission in setting the European agenda, astoundingly little attention has been given to this particular aspect of the EES. Empirical inquiry into the Commission's role within the Union focuses both on the innovative and policy formation aspects of EU decision-making and on the routine and administrative aspects (Nugent 2000: 20). Of these two strands of the literature, however, the former has been by far the most widely studied. Indeed, the most common claim with regard to the Commission's influence refers primarily to its ability to act as a "policy entrepreneur" or "informal agenda-setter" (Pollack 1997)..$^{5}$ However, despite the strong academic bias in favour of its informal agenda-setting power, the Commission's capacity for "purposeful opportunism" (Cram 1994) reaches far beyond its ability to develop and actively promulgate innovative proposals. Rather, the Commission enjoys extensive powers right through the policy chain and although it operates within frameworks, references, and specifications which have been laid down by the Council, "the extent to which the Commission is constrained when it undertakes theses roles should not be overstated" (Nugent 2000: 20). The Commission enjoys, for instance, substantial room for manoeuvre at the implementation stage of the policy process since many such decisions require minor adjustments to existing legislation that usually take the form of Commission regulations or decisions. In formulating this administrative legislation, the Commission has to work though specialized committees composed of national representatives, which serve a more or less restrictive function on the Commission's power (Franchino 2000). Likewise, the Commission's monitoring and legal guardianship responsibilities - although a relatively neglected area of inquiry - are vital for any analysis of the role of the Commission with regards to the process of European integration (Mendrinou 1996: 17, Levy 2000, Peters 2000). Crucially, this study's particular emphasis on the Commission's role within the institutional framework of the EES since 1997, places it within the second stand of this sizeable body of literature.

How, then, is the Commission conceived within the body of literature surrounding the EES? Commenting on the Commission's role within the framework of the OMC more generally, Borrás and Jacobsson note that, compared to the classic "Community method" of legislating, "the heads of states have increasingly taken the lead with regards policy initiatives, and therefore the Commission's formal monopoly of initiative has subsequently vanished" (2004: 198). More importantly, it is arguably the case that the bulk of the literature tends to overlook the role of the Commission, implicitly assimilating it to an impartial arbitrator, chiefly responsible for "oiling the wheels" of the European Employment Strategy policy process. However, it is a heroic conjecture to suppose that the Commission oversees the EES in an entirely detached manner. Conceptualising the Commission as disinterested authority that simply overlooks co-ordinative initiatives taking place among Member States repudiates a substantial body of empirical work demonstrating how 
the Commission, since its inception, has continuously pushed to increase its powers within the EU and promoted a further integrationist agenda with line with its own interests.

More recently, however, certain commentators have voiced the possibility that the Commission is effectively playing a key role as norm entrepreneur. Dehousse contends that although "the Commission does not enjoy the institutional prerogatives that have been its strength in other areas [...] the search for cognitive convergence, which is as the heart of the OMC, involves tasks the Commission is better able to accomplish than any other institution" (2002: 14). These early tentative suppositions about the Commission's entrepreneurial role stem from its institutional centrality within EES processes (see below) and its resulting hypothetical capacity to "orient debates, to propose indicators and benchmarks, to advance new ideas, and to pressure member states to comply with guidelines, benchmarks and recommendations it issues to individual member states" (de la Porte and Pochet 2004: 72; see also, Borrás and Jacobsson 2004: 198, de la Porte and Pochet 2003, Goetschy 1999, Schmidt 2000). According to Dehousse, the particularities of the EES require that the Commission "play its cards differently than it does in the context of common policies" (2002: 14). Rather than forcefully imposing itself as a leading actor, the Commission may well achieve more by doing less. Trubek and Mosher (2003) claim that by adopting a seemingly more self-effacing attitude, the Commission appears to have gradually increased its influence over employment matters. In the same vein, Jabko (2004) claims that in order to compensate for it lack of formal leadership role within the OMC, the "Commission must strive to acquire informal influence based on expertise and its knowledge of policy issues" (quoted Dehousse 2002:15). To date, however, such claims largely remain in the realm of speculation. Commenting on the existing research in the field of the EES, de la Porte and Pochet note that "there have been no empirical test on the extent of the Commission's influence as a norm entrepreneur" (2004: 72).

\section{Detailing the institutional framework of the European Employment Strategy}

Largely considered to be the flagship as well as the original blueprint for the OMC, the EES was launched at the Luxembourg Jobs Summit (November 1997) on the basis of the new provisions established in the Employment Title of the Treaty of Amsterdam (Art. 125-30). Prior to the 2005 revamp of the Lisbon Strategy - and the concomitant revision of the EES - the annual procedure for the coordination of employment policies (Art. 128) was as follows: the European Commission drafted a set of employment guidelines, ultimately decided upon in the Council by qualified majority voting (QMV), that Member States were expected to consider when formulating national employment policies. Based on these guidelines, national governments established annual National Action Plans (NAPs) on employment that were subsequently submitted to the Commission for cross-national comparison and evaluation. The results of the cross-national comparison were then published in an employment report (the "Joint Employment Report" - JER) to be approved jointly by the Commission and the Council. The JER included the comparison and benchmarking of countries and the identification of best practices. Moreover, based on proposals made by the Commission, the Council could by QMV make recommendations to Member States to adapt their national policies to employment guidelines. Finally, the European Council was charged each year to adopt conclusions on the employment situation within Member States on the basis of the JER.

However, the year 2005 saw a major review of the architecture of the EES. As part of the Commission's proposal for a refocusing of the Lisbon strategy, a new governance of the EES, fundamentally aiming to integrate employment policies with macroeconomic and microeconomic policies, was established. Although in practical terms the EES's annual and iterative process remains largely unchanged, employment guidelines no longer exist as a separate policy document; rather, the new integrated guidelines for employment now exist alongside Broad Economic Policy Guidelines (BEPGs). Member States' National Action Plans for employment have thus been incorporated into a single document - re-named National Reform Programmes (NRP) - that 
contains both employment and economic policy priorities of national governments. Similarly, an annual Progress Report on Jobs and Growth has replaced the Joint Employment Report.

Although the latest revision of the European Employment Strategy poses important questions with regards to the precise impact of such reforms on the priorities of the Lisbon Strategy and the status of the EES therein, ${ }^{6}$ the formal roles and responsibilities conferred upon the Commission in the context of the EES remain largely unchanged. As well as being charged with the role of neutral facilitator, able to discharge national governments of certain sensitive tasks (i.e. evaluating Member States' efforts in the field of employment by submitting the initial draft and jointly approving the annual Progress Report, proposing employment guidelines as well as recommendations), the European Commission's presence within the Employment Committee $(E M C O)^{7}$ - the central advisory body at the heart of the EES - further suggests a policy-brokering role in which the Commission is responsible for mediating the position of Member States in an attempt to reach consensus. Crucially, then, these formal specifications will serve as a benchmark against which to examine the role of the Commission within the EES since 1997.

The above-mentioned Employment Committee forms the nucleus of the EES round which all employment procedures are organized and, accordingly, the main focus of this research project. The following paragraphs expose the institutional particularities of EMCO; this descriptive exercise will serve to provide vital background information for the empirical part of this enquiry.

\section{The Employment Committee as the Nucleus of the EES}

According to the Treaty (Art. $130 \mathrm{EC}$ ), EMCO is an advisory body, the main objective of which is to promote co-ordination between Member States with regard to employment and labour market policies. Its tasks include monitoring the employment situation and employment policies in the Member States and the Community, formulating opinions at the request of either the Council or the Commission or on its own initiative, and contributing to the preparations of the Council proceedings referred to in Article $128 \mathrm{EC}$. Additionally, quite apart from strict deadlines and stringent procedures that frame the EES's annual cycle, national representatives within EMCO also partake in a "Peer Review Programme" that seeks to encourage mutual learning at all levels and enhance transferability of the most effective policies within key areas of the EES. In practice, a host country voluntarily proposes to present a particular aspect of its labour market programme; Member States that have an interest in the project then decide to participate in the peer review session concerned. National delegations are assisted by external experts whose task is to access the relative success of the experience in the host country as well as the possibility of transferability of such a practice to the peer country.

The Employment Committee's membership consists of two ordinary and two alternate members from each Member State as well as two members from the Commission. Member States are required to elect a Chairperson from among the members of the Committee for a non-renewable term of two years. In performing his or her duties, the Chairperson is advised by a steering group comprised of four Vice-Chairpersons, two of which are elected by the Committee (it is often the case that they hold the office of Chair of EMCO's two sub-groups - see below), the other two ViceChairpersons are representatives of the present and upcoming Presidencies of the Council. ${ }^{8}$ As well as effectively chairing EMCO meetings, ${ }^{9}$ the Chairperson also works in close collaboration with the Secretariat of EMCO whose tasks include preparing and circulating all documents that are discussed in the Committee as well as drafting Committee opinions. Paradoxically, although formally accountable to the Chairperson, the Secretariat of EMCO is placed under the aegis of the Commission since it is the Commission that formally designates members of its own staff to fill the ranks of the Secretariat. Finally, EMCO has two sub-groups, the Indicators group and the Adhoc group. The Indicators group, charged with assisting EMCO in the selection and development of indicators required to monitor the Employment Guidelines, constitutes an active body within 
the EES since indicators are regularly revised in light of statistical developments and new policy priorities. ${ }^{10}$ The Ad-hoc group assists the Employment Committee by engaging in preparatory discussions on specific issues in view formulating eventual opinions in EMCO. ${ }^{11}$ Both sub-groups consist mainly of technical experts from ministerial level.

According to Borrás and Jacobsson, the notion of "partial delegation of power" successfully captures one of the most important characteristics of the OMC arrangements, namely, that in formal terms the division of tasks between the EU and Member States remained unchanged (i.e. the subsidiarity principle remains intact), but beneath this formal surface, a series of apparently minimalistic changes might have deep effects on EU politics (2004: 197). Crucially, in the case of the EES, it is the Employment Committee that best embodies these doubts and ambiguities about this new form of Community competence. As well as being the focal point of the day-to-day proceedings of the employment strategy, the Employment Committee stands as the only preparatory body before the Council level and although final decisions (with regards to approving guidelines, sanctioning the annual Progress Report and delivering recommendations) are reached in the Labour and Social Affairs Council by qualified majority voting, such a procedure constitutes a mere stamp of approval on decisions that have been effectively reached within EMCO.

\section{The Advocacy Coalition Framework}

This study follows in the footsteps of a growing number of scholars within the field of European studies that have utilized the ACF in order to shed some light on the increasingly complex set of relationships evolving within the EU (Parrish 2003, Kendall 2001, Radaelli 1999, Rhinard 2002, Weber and Christophersen 2002, Zito 2001). Reasons for this growing enthusiasm for the ACF relates to its utility as a coherent ordering framework capable of rationalizing the complex dynamics at play within the Union. In effect, the ACF is based on a number of fundamental hypotheses and constitutes a comprehensive lens through which to understand and investigate policy processes (Sabatier and Jenkins-Smith 1993). The following section details certain principal features of Sabatier's theoretical framework, which stand at the heart of this empirical inquiry.

\section{Policy Subsystem Maturation}

The unit of analysis of the ACF is that of policy subsystems - defined as a set of "actors from a variety of public and private organizations who are actively concerned with a policy problem or issue [...] and who regularly seek to influence public policy in that domain" (Sabatier 1998: 99). Within each subsystem, the ACF assumes that actors can be aggregated into a number of "advocacy coalitions" who both "(a) share a set of normative and causal beliefs and (b) engage in a non-trivial degree of co-ordinated activity over time" (Sabatier 1998: 103). Essentially, the policy process is considered to be a competition between advocacy coalitions that share a particular belief system about how a specific policy problem is structured and how it should be addressed. The main point of interest here is that a new or nascent policy subsystem (i.e. one in the process of forming) will be characterized by a relatively fluid situation which will gradually give way to the emergence of stable coalitions over time; this maturation process is deemed to take place over a decade or more (Sabatier 1998: 111). According to Sabatier, the process informing the formation of competing coalitions is based on the dissemination of information concerning the seriousness of the problem, its origins, alternative means of addressing the problem and their costs.

\section{Advocacy Coalitions and Policy-Oriented Learning}

Once established, advocacy coalitions may engage in an inherently conflictual or co-operative rapport (Sabatier 1998: 118-9). Under the former state of affairs, competing coalitions will 
aim to influence the behaviour of various governmental authorities in order to realize the policy objectives implicit in their belief system. In this, advocacy coalitions use venues provided by the constitutional structure of the political system within which they operate (Sabatier and JenkinsSmith 1999: 142). The ACF assumes that policy change is a result of the transformation of a hegemonic belief system within a policy subsystem, or more radically, its substitution by the belief system of a competing advocacy coalition. However, an alternative scenario is introduced by Sabatier, who holds that "in situations in which all major coalitions view a continuation of the current situation as unacceptable, they may be willing to enter negotiations in the hope of finding a compromise that is viewed by everyone as superior to the status quo" (Sabatier 1998: 119). In short, coalitions can agree on a positive sum solution rather than engage in a zero-sum game. The end result of such a process is not a principal and domineering coalition and several minority coalitions; rather, there emerges a situation of "power sharing" among coalitions. In such cases, negotiations are led by a "policy broker" respected by all parties and viewed as relatively neutral. According to Sabatier and Jenkins-Smith, policy brokers form a category of actors "whose principal concern is to find some reasonable comprise that will reduce intense conflict"; a role traditionally performed by "elected officials (particularly chief executives) and, in some European countries, like Britain and France, of high civil servants" (1993: 18-9; 27). Crucially, Sabatier notes that the roles of "broker" and "policy advocate" (i.e. the normal, unconstrained advancement of policy preferences of advocacy coalition members) are indistinct, with policy brokers occupying positions within different coalitions, but overridingly concerned with limiting conflict.

Moreover, one of the most influential aspects of the ACF lies in the contention that policy change is not simply the result of strategic action among various interests, rather, "policy-orientated learning" within and between coalitions is considered to play a vital role in such a process. ${ }^{12}$ According to Sabatier the conditions for learning across the belief systems of different coalitions are similar to those for a successful "consensus regime" (1998: 119). However, as well as demonstrating a marked and long-standing commitment to consensus-formation, ACF theorists consider that policy learning requires the presence of a professionalized forum whose participants are selected on the basis of their technical competence and where professional norms guide discussions (Sabatier and Jenkins-Smith 1993: 53-5).

\section{Coalitions, consensus and strategic action: stepping behind the scenes of the European Employment Strategy}

Having established certain fundamental tenets of the advocacy coalition framework, the following sets out to examine the EES through the lens of the ACF, while laying particular emphasis on the role of the Commission therein. Before engaging in the analysis, it is important to note that prior to the inception of the EES, employment policy was largely considered to be a domestic issue to be dealt with at the national level. As a result, distinct and self-contained national policysubsystem coexisted alongside one another. However, the Treaty of Amsterdam transformed the political landscape in the sphere of employment policy. The Employment Title effectively marked the emergence of a new policy-subsystem within the European arena that would henceforth exist in conjunction with the national policy-subsystems of individual Member States; thus, leading to situation of "multiple nested subsystems representing different territorial units" (Sabatier 1998: 115).

Notwithstanding the importance of their original institutional design and expectations in terms of potential, institutions are living entities and their practical functioning often differs from their original intent as inscribed in the Treaty (Pierson 1996). Thus, the analysis conceives of the EES as a practice stepped in reality and evolving across time. Considered through the lens of the $A C F$, this investigation seeks to ascertain whether certain advocacy coalitions have effectively emerged, whether they maintain a consensual or competing relationship, and finally where the Commission stands vis-à-vis these coalitions and what role it assumes within this policy-arena. 
Conflict or consensus: establishing the driving force at the heart of the EES

Both national and Commission officials within EMCO noted in their interviews that the more fluid situation of the EES's early days has slowly given way to the gradual emergence of two competing coalitions within the EU arena. ${ }^{13}$ On one hand, respondents underlined the existence of a liberal coalition whose membership typically comprises the United Kingdom (UK), Denmark, Finland, the Netherlands, Italy, Spain (under Prime Minister José Maria Aznar 1996-2004), and new member States such as Slovakia, Poland, Cyprus and Malta. This coalition distinctly tends towards a "US style" approach to employment policy, which stresses the importance of individual responsibility in a residual welfare state. Likewise, emphasis is chiefly placed on a fundamental commitment to labour market flexibility as a means of retaining national competitiveness in an open economy. On the other hand, a social model coalition recruits its members within the national governments of France, Belgium, Sweden and Spain (since 2004). Not repudiating the importance of full employment, this advocacy coalition gives particular emphasis to the integrity of the individual and the need to provide a certain measure of security and quality in his/her work. Crucially, the EU's geographical expansion towards Eastern Europe stands as an important landmark in the maturation process of this policy subsystem. Indeed, EMCO officials were keen to remark that Union's enlargement towards central and east European countries (CEEC) altered the balance of power at the heart of the EES since new Member States have been inclined to joint the ranks of the "liberal" coalition. ${ }^{14}$

In practice, the structuring of the political dynamics within the EES around two distinct advocacy coalitions will be more of less discernible depending on the policy issue under consideration. According to Sabatier and Jenkins-Smith, the heightened visibility of these coalitions is a function of whether certain analytical claims threaten core values and precepts of either belief systems (1993: 49). Thedvall's in-depth study of policy-making dynamics at the heart of the EES offers a valuable insight into the balance of power and the relative importance of these advocacy coalitions. Between July 2000 and December 2001, three successive presidencies of the EU (France, Sweden and Belgium) - all members of the "social model" coalition - joined forces to place the issue of "quality in work" (i.e. a horizontal objective introduced in the 2002 Employment Guidelines) onto the EES agenda. Conversely, the UK, Netherlands and Italy appeared markedly less eager to establish this new policy priority under the banner of the European Employment Strategy (Thedvall 2006: 53-66; 144-151). Finally, while the structuring dynamic of these two belief systems provides a valuable insight into the workings of the EES, a more rigorous examination of the membership of both advocacy coalitions ${ }^{15}$ and a comprehensive mapping of their belief systems lies beyond the scope of this research project. Rather, the point here is to ascertain whether consensus has been effectively established as the driving force within EES or whether such coalitions maintain a largely conflictual rapport.

The in-depth interviews carried out with members of the Employment Committee bring to the fore numerous practices and processes clearly indicating that the EES is fundamentally anchored within a consensual and deliberative ethos. In a conscious effort to guard against any form of infighting within the Committee, EMCO's Rules of Procedure explicitly establish a proviso of simple majority voting. ${ }^{16}$ However, this voting provision is rarely drawn upon in Committee proceedings; in the eyes of national delegates, its utilization amounts to a failure by the Committee to fulfil its original and primary duty of consensus formation. As one national official notes "the culture of EMCO has never been one of bringing things to votes or isolating people and forcing them to back down". Significantly, Thedvall's enquiry into the process surrounding the development of "quality of work" indicators depicts a state of affairs characterized by a productive analytical debate between members of different coalitions (Thedvall 2006: Chapters 5, 6). Moreover, respondents noted that the overarching principle of "consensus formation" compels national representatives to bow to certain agreements that fall short of being their favoured outcome. ${ }^{17}$ 
National officials further laid emphasis on a mutually beneficial rapport in which Member States are able to draw on each other's experience in the field of labour market policies. However, EMCO's overburdened agenda and strict deadlines imposed by Council proceedings leaves limited room for discussion and deliberation within the Committee itself. In effect, there is some indication that such "learning dynamics" - taking place both within and across coalitions - have gradually shifted from EMCO to the Committee's two sub-groups as well as the Peer Review Programme. ${ }^{18}$ Further still, because of the cumbersome nature of the official proceedings that characterize EMCO, national delegates tend to establish bi-lateral exchanges and discussions outside the framework of the EES. Understood through the lens of the ACF, it appears that EMCO's sub-groups and the temporary groupings of national experts convened in the context of the Peer Review Programme bare a strong resemblance with the aforementioned "professional fora", which stand as critical institutions for promoting policy-orientated learning across belief systems (Sabatier and Zafonte 1997).

As noted elsewhere, the mode of interaction within the Committee is largely a function of the issue under discussion (Jacobsson and Vifell 2004). Decisions that attain political visibility at the level of the European Council tend to engender a rather strenuous bargaining process between Member States; a prime example being the drafting or revision of the Employment guidelines, which often entails convolved intergovernmental negotiations as well as confrontational dealings with the Commission. Notwithstanding these periodic limitations to the Committee's consensus-seeking dynamic, the above analysis indicates that the Employment Committee seemingly operates in a manner wholly consistent with what Sabatier refers to as a "consensus regime" (1998: 120).

Finally, the position of the Chairperson is held in esteem by Committee members, who tend to stress the sometimes arduous task of establishing "something everyone can live with". At no point did national delegates suggest that the Chairperson and his steering-group made use of their position to slant discussions towards their own particular views; rather, the Chairperson is largely considered to be the guarantor of objectivity, neutrality, and the diligent application of EMCO's Rules of Procedure.

In sum, as foreseen by the ACF, the maturation of the EES has effectively led to the emergence and gradual consolidation of two advocacy coalitions. However, rather than falling prey to a confrontational rapport, Member States have primarily sought to uphold an inherently consensual relationship. Crucially, Sabatier envisages that in the case of a consensual co-existence of several minority coalitions in a situation of "power-sharing", negotiations are led by a policy broker overridingly concerned with limiting conflict. The above analysis suggests that such responsibility lies with the Chairperson. Where, then, does the Commission stand? Does this policy-brokerage role fall solely on the Chair of EMCO or does the Commission bare some influence on the process? The following section seeks to address these questions and both determine the role and gauge the influence of the Commission within the EES.

\section{A policy-broker? Detailing the extent of the Commission's powers within the EES}

By and large, national officials were eager to commend the Commission's ability to draw out a consensus within the Employment Committee. Most notably, the talent of Odile Quintin - the then Director-General of DG Employment, Social Affairs and Equal Opportunities, and Commission representative within EMCO between May 2000 and January $2006^{19}$ - for achieving compromise within EMCO was collectively praised by national officials and has been an important factor in her gaining the unanimous respect of Committee members. National representatives, who tend to appreciate the Commission for the expertise and competence it has accumulated in the field of employment, do not decry this consensus-seeking role. Thus, although not formally specified in the Employment Title of the Amsterdam Treaty, Commission officials within EMCO effectively act as policy-brokers within Committee proceedings. Crucially, however, the influence of the 
Commission within EMCO will be function of the forcefulness of the Chair. Whereas a strong Chair will direct Committee proceedings a weak Chair will inevitably allow the Commission to assert itself as a dominant actor within EMCO. ${ }^{20}$

As well as assuming a policy-brokering role, respondents further recognized that the Commission effectively acts as a referee and guardian of fair play. The drafting of state-specific recommendations and country fiches (which form the basis of the annual Progress Report) lays bare the underlying principle of fair treatment across the board, that is to say, that Member States in similar situations will be treated similarly. Thus, in undertaking its fundamental role of reporting on national governments' efforts and advances in the field of labour policy, the Commission is broadly perceived as a neutral observer and administrative facilitator within the European Employment Strategy.

However, although certain processes at play within EMCO indubitably indicate that the Commission is overridingly concerned with facilitating compromise and consensus between Member States, certain practices adopted by Commission officials clearly expose a competence-maximizing rationale. In effect, the Commission has consistently sought to further its standing within the EES by (1) taking advantage of its "special relationship" with the EMCO Secretariat and (2) carefully developing a fictitious right of initiative within the EES.

\section{Saddling the Secretariat}

The setting-up of the Employment Committee in 2000 sparked considerable debate between national governments and the Commission as to whether the Secretariat should be placed under the aegis of the Commission. At the heart of this discussion lay the controversy surrounding the (im)partiality of the Commission members of the Secretariat. Members of this support team are condemned to "wear two hats" and spilt their loyalty between both the Commission (of which they are members) and the Chairperson (to whom they owe their allegiance). A chief concern voiced by national officials at the time hinged on the fact that the Commission might influence the work of the Secretariat and inject its own preferences into EMCO proceedings. As time has elapsed and the Employment Committee has slowly found its bearings, a critical question comes to the fore: Has this concern proved to be justified or was it simply an unwarranted apprehension of national governments?

The key role of the Secretariat, and indeed the locus of its political power, lies in its capacity to draft the opinions of the Employment Committee. ${ }^{21}$ Thus, in view of the particular institutional design cited above, the risk arises that in drafting EMCO opinions to be presented to the Council for approval, the Secretariat will effectively trim things towards the Commission's views. ${ }^{22}$ Overall, this concern has proved to be well founded, but a forceful chair may provide the essential checks and balances needed to counter any form of veiled interference on the part of the Commission.

A British official recounts how informal checks and balances have been established in the form of a pendulum effect whereby draft opinions shuttle back and forth between the Commission and the Chairperson's national support team operating back home. Thus, although it remains the responsibility of the Secretariat to draft the initial version of EMCO opinions, this document undergoes successive modifications by the Chairperson and the Commission before a compromise is finally agreed upon by both parties. However, as a senior Commission official candidly remarks, "a weaker chair might see the Commission's role enhanced with the current set-up". In effect, not all Member States are able to provide such a strong administrative check on the Commission's dealings with the Secretariat. In such cases, the Commission enjoys a certain leeway in shaping the content of the Committee's written opinions. Particular criticisms levied against the Commission draw attention to its tendency to omit certain standpoints clearly expressed by national 
representatives during Committee meetings and, in certain cases, amending the position taken by national representatives with regards to certain issues. ${ }^{23}$ By and large, these practices have prompted an underlying feeling of wariness among national officials vis-à-vis the Commission, thus undermining somewhat the collaborative environment depicted above. It is important to stress, however, that the Commission's capacity to subvert the content of the Committee's opinions by means of such practices remains limited.

\section{Upholding the ideal of the Commission's sole right of initiative}

At the time of its inception, the institutionalisation of the EES entailed a significant degree of uncertainty among Member States with regard to the practical operationalisation of the abstract processes defined in the Employment Title of the Amsterdam Treaty. Although formal roles and responsibilities had been defined in Articles 125-130 EC, the more informal aspects of their effective implementation were yet to be established. In effect, early meetings of EMCO were characterized by a fluid situation in which central actors in the process were "searching" for their particular standing vis-à-vis other actors. The European Commission seized upon this opportunity to fill a political aperture that emerged in the wake of the EES. Effectively, the Commission sought to strengthen its competence within the EES by supplementing its formal powers - lawfully defined in the Treaty - with informal powers that it bestowed upon itself. Theses informal resources hinge on the fundamental concept of "authority"; understood as the voluntary submission to legitimate power. Following Scott (1987: 286), legitimacy refers to "the property of a situation or behaviour that is defined by a set of social norms as correct or appropriate". In the case of the EES, such social norms derive from the stable role structure that emerged within the realm of the classic "Community method" and which guides the expectations of national governments vis-à-vis the Commission's standing in the EU (Scott 1987: 306). Thus, the Commission capitalized on its prominent role within other committee structures (most notably Council working groups and implementation Committees, both of which are placed under the aegis of the Commission) in order to establish an illusory right of initiative with the Employment Committee.

Article 130 of the EC Treaty notes that, as well as contributing to the preparation of the Council proceedings referred to in Article $128 \mathrm{EC}$, the Employment Committee will "formulate opinions at the request of either the Council or the Commission or on its own initiative". On the whole, the vast majority of the papers set forth for discussion within EMCO are Commission papers. In such cases, according to the Treaty, the Commission is required to simply present a paper and take note of the opinion duly expressed by the Committee. However, based on the responses collected during this study, the effective working procedures established within EMCO depict an altogether different scenario. Not content with simply presenting a paper for discussion, the Commission systematically seeks to defend its proposal in manner analogous to its role within Council working groups. ${ }^{24}$ Thus, by mimicking legitimate behaviour that is expected of it within the CCM, the Commission has successfully transposed a long-standing role structure into a new institutional framework.

The practice of presenting and more importantly defending Commission papers in the framework of the EES was introduced right from the early beginnings of the Employment Committee. As one national official recalls; "there is nowhere written that this is the way that it should be. I was at the meeting when EMCO was set up, and I think people just said this is the way the world works, the Commission does this. No one will challenge it". However, it would be wrong to equate such a practice to an innocent automatism on the part of the Commission, rather, it purposefully sought to capitalize on the authority it enjoyed within the EU and uphold against all odds the ideal of the Commission's "sole right of initiative" that is so deeply ingrained in national representatives understanding of how the EU operates. A Commission official - who considers himself to be one of the "founding fathers" of the EES - clearly underlines the calculative strain to the Commission behaviour, when he notes: "the Commission is very jealous of its role as leading force in the EU [...] Clausewitz says that if there is an empty military space, somebody will try to fill it. Well, 
we are trying to fill it here (i.e. establishing the Commission's right of initiative within EMCO), even if we do not have the exclusive competence to do so". Crucially, then, the Commission was careful to reinstate its dominant standing and mould its rapport with national representatives to its advantage at an early stage; before the traditional "order of things" and the long-established power relations between Commission and Member States could be called into question.

The Commission's unyielding attitude occasionally causes a mélange of friction and lassitude within EMCO; particularly within the Indicators group where national representatives are charged with defining indicators that often carry important political implications with regard to measuring Member States' progress in the field of employment policy. A French official who sat on the Indicators group notes, there was the "feeling that, on many occasions, the Commission presented them [Member States] with a fait accompli and that they were obliged to accept the indicator so as not to break the consensus". He remarks that the Commission largely considers the Indicators group as an "expert group at its disposal" that serves to inform Commission proposals but does not have the right to take decisions of its own; "they expected us to accept any paper - perhaps with minor alterations - that they put on the table". Crucially, under such circumstances, where the possibility for discussion is fundamentally limited by the Commission's intransigent attitude, the Indicators group sometimes comes to a "false consensus". In other words, the President of the Indicators group managed to draw up a simple majority in favour of a Commission proposal by exhorting national representatives "not to break the consensus". However, when the proposed indicator reached EMCO for final approval, the debate started up again: he notes "this happened very often".

Following the initial instatement of its initiating powers within the novel framework of the Employment Committee, the Commission has also been careful to uphold its strategic position within EMCO. To date, the rare opinions presented by national governments for consideration within the Committee have largely come as a response to an original paper proposed by the Commission. The rare national delegations that have sought to challenge this modus operandi have been systemically rebuked by the Commission by means of its formal powers. Commenting on the efforts of a member of EMCO to propose the formation of a working group on "making work pay", a French official observes "the Commission did everything to prevent this proposal from being considered". When he tried to propose it, "it was quite late on in the day and the Commission considered that we did not have time and also argued that it was too expensive. Basically, the Commission was doing all it could not for this to happen". Finally, Member States threatened to finance the project amongst themselves, thus the Commission, realizing that it ran the risk of being excluded from the working group, accepted to partially finance this initiative. Although anecdotal, this episode clearly reveals how the Commission will utilize its formal powers (both logistical and financial) in order to sustain its exclusive right of initiative within the Employment Committee.

The Commission's tendency to effectively emulate within the Employment Committee the same behaviour it adopts within Council working groups also carries important implications with regard to its particular understanding of the nature of the EES and demonstrates its incapacity to break away from the culture of constraints and obligations attached to the traditional hard law model of EU governance. As one national official notes, "Some parts of the Commission don't get it. The Employment Strategy belongs to us, we do it because we want to do it, and it is our policy and priorities; and we are not naughty school children that have to be chased and forced. Some parts of the Commission that attend EMCO behave as if this is about imposing an obligation on us that we would rather wriggle out of. That is again part of their administrative history and culture, that they think in terms of compliance and obligations under regulations and directives".

Finally, it must be noted that the Commission's authoritative "informal power of initiative" carries tremendous implications with regard to its effective influence in the context of the EES. Crucially, the Commission has extended its role from mere policy broker and administrative facilitator, 
charged with drawing out a consensus within EMCO and reporting on the progress of national government with regard labour policy, to that of policy initiator, capable of setting the agenda of the Employment Committee. Ultimately, then, the Commission has endowed itself with the critical role of norm entrepreneur. Its capacity to advance new ideas and frame issues by means of Commission papers as well as its expertise and knowledge of policy issues, which it uses to defend its proposals and orient debates, ${ }^{25}$ places the Commission at the heart of the EES, capable of moulding the understanding and preferences of national governments. The extent of this influence is impossible to quantify in precise terms; however, the reality of its formal and informal roles within the European Employment Strategy leaves little doubt about the importance of the Commission's normative powers.

\section{The Commission's agenda within the EES}

Having established the significance of the Commission's powers within the institutional framework of the EES, we are faced with the substantive question of what is the Commission's agenda. Two important aspects emerge from this research.

\section{The Commission as a Policy Advocate}

A crucial characteristic of policy brokers within Sabatier's model of consensus regimes is their clear predilection to be affiliated with a particular advocacy coalition while simultaneously upholding an overriding concern of limiting conflict and promoting consensus. This conjecture appears particularly suitable in the case of the EES. Numerous respondents insisted on the Commission's clear ideational inclination toward the "social model" coalition headed by the Francophone countries Belgium and France. As outlined above, the Commission's powers with regard to setting the agenda of EMCO meetings by tabling the vast majority of discussion papers as well as its propensity to orient the wording of final Committee opinions, undoubtedly serve as important tools for disseminating its policy preferences. Moreover, the pyramidal hierarchy of DG employment, noted by certain respondents, places the Director General at the heart of the Commission's ideational stance. Crucially, Odile Quintin was frequently reported to exert a strong influence in tabling papers, directing discussions, and constructing consensus, while simultaneously trying to inseminate her own more "socially-orientated" concerns into the proceedings. Ms Quintin's political orientations are well know to all EMCO officials and accepted as constituting an intrinsic aspect of the Commission's disposition. However, it is important to note that the Commission's status as policy advocate is a secondary aspect of its role within the EES. In the eyes of all respondents, it is indubitably the case that the Commission acts first and foremost as administrative facilitator, policy-broker and mediator of competing coalitions and conflicting national interests within the Employment Committee.

\section{Reining in national governments and increasing Community competence}

Several respondents bear witness to the Commission's efforts in perpetually urging national governments to establish more indicators in order to uphold the employment guidelines; a tendency that has led many officials to deplore a situation of effective saturation of statistical indicators and a lack of clear visibility with regard to the direction and vision at the heart of the EES. In effect, the proliferation of indicators constitutes a vital means of strengthening the standing of the Commission within the EES by virtue of the monitoring role assigned to it in the Treaty. The drafting of the annual Progress Report on Jobs and Growth, a reporting exercise largely orchestrated by Commission officials organized in separate "country desks", ${ }^{26}$ constitutes a valuable means of applying a soft form of pressure on national policy-makers since low rankings on common indicators may be utilized by national opposition parties and interest groups in denouncing the incompetence of the incumbent government. ${ }^{27}$ Moreover, many respondents noted that the 
Commission has traditionally been keen to expand the policy issues that effectively come under the heading of the EES and urge for discussion in other adjacent spheres of the field of employment. The two priorities depicted above follow the same competence maximizing logic described by Jobelius (2003) in his study of the formulation of the 2003 guidelines. In effect, the Commission has continuously demonstrated a clear preference for means- rather than result-orientated indicators as well as ascribing clear quantifiable targets to the employment guidelines. Thus, it emerges from these particular examples, that the Commission's propensity to strengthen its own standing within the practical processes of the EES serves the ultimate goal of reining in national governments within the ambit of Community competence by extending the realms of applicability of the EES and increasing the number and effectiveness of its monitoring tools.

\section{Conclusion: assessing the powers of the Commission within the EES}

This study draws attention to two under-researched aspects of the OMC so far. First, as mentioned in the opening section of this paper, the European Commission's tendency to seek to increase its standing within the EES needs to considered in the context of the larger body of literature surrounding this institution. Accordingly, this study marks a first tentative step into a largely overlooked aspect of the Commission's role within the EU, that is, its role within new modes of governance. A fundamental belief that prevails within political and academic circles hinges on the centrality of the national governments within the EES. The Council, so the argument goes, remains at the heart of the EES processes, thus barring the European Commission from any form of substantial power within this new policy area. This line of reasoning is clearly set forth by the former Dutch Minister of Social Affairs and Employment, Klass De Vires, who notes that "because the Council and its official gatekeepers play a decisive, identifiable role, the Commission cannot exercise too dominant an influence on European employment policy. Employment is primarily the Member States', and therefore the Council's, affair". ${ }^{28}$ However, inferring the powers of an institutional actor purely on the basis the legal provisions stipulated in the Treaty fails to offer a comprehensive account of the reality of the power games at play within the EES. The Employment Chapter of the Amsterdam Treaty granted extensive formal responsibilities to the Commission. As detailed above, with regard to certain of these prerogatives the Commission has maintained a substantial degree of professionalism and impartiality, most notably in the case of the drafting of the annual Progress Report and the formulation of state-specific recommendations. Likewise, national representatives were also keen to commend the Commission's policy-brokering role and its remarkable ability to draw out consensus within EMCO. However, this laudable behaviour is not apparent within all the spheres of responsibility that fall under the ambit of the Commission's mandate. While significant practices taking place in EMCO expose the Commission to be a responsible facilitator and a valuable policy-broker within the EES, there is evidence that such unprejudiced administrative and brokering efforts have sometimes been marginalized and replaced by altogether more self-interest oriented practices. The foregoing analysis calls attention to two significant tactics employed by the Commission in its efforts to strengthen its standing within the EES. First, unless a strong Chairperson - with an effective national support team at his/her disposal - provides the necessary checks and balances on the drafting of EMCO opinions, the Commission will invariably seek to influence the wording of these documents by means of Employment Committee Secretariat which it staffs. Second, the Commission's endeavour to further its standing within the EES has led it to establish and jealously sustain a fictitious right of initiative. Crucially, this informal power of initiative places the Commission at the very heart of the EES; indeed, (1) its capacity to set the agenda within EMCO as well as (2) its ability to uphold it proposals and defend its ideas by means of extensive expertise places the Commission in the position of norm entrepreneur within the EES able to influence national representatives understanding and preferences. Crucially, the Commission's self-serving image as impartial mediator within the EES has served to both justify its central standing within the Employment Committee and to lay claim to certain roles and responsibilities above and beyond those assigned to it at Amsterdam. 
Secondly, the analysis of the policy process and evolutionary dynamics of the EES through the lens of the ACF effectively opens up an altogether new and promising avenue for future research. Although commentators have repeatedly lamented the empirical deficit within the body of literature surrounding the EES and more generally the OMC (de la Porte and Pochet 2002: 287; Zeitlin 2005: 447), few have denounced the significant empirical bias in this field of research. As outlined above, preliminary empirical studies have almost exclusively been concerned with evaluating the impact of the EES within the national arena. Accordingly, very little attention has been given to the practical operationalisation of the processes that lie at the heart of the European Employment Strategy; rather, commentators tend to rely heavily on numerous normative depictions and abstract theorization with regard the EES's potential as a mechanism for promoting experimental learning and deliberative problem-solving. While not discarding the validity of such contentions, this study argues for a stronger emphasis on power relations within the workings of the EES. Indeed, the consolidation of two distinct advocacy coalitions - a "liberal" and a "social model" coalition - ievidenced in this study carries deep implications in light of the prevailing assumption that the EES is a an inherently apolitical process. ${ }^{29}$ Crucially, then, far from constituting a mere platform for discussion and policy learning, or - as certain commentators have stressed - for defining and building consensus around a distinctive European social model (Vandenbrouke 2002, Ferrera 2001), the EES has instead emerged as a prominent venue for articulating and promulgating two competing visions of a common social model for the EU. A potential avenue for future research could be to map the particular belief systems, to examine the membership, and more importantly to address the balance of power between these two advocacy coalitions across time.

\section{Notes}

1) In general terms, this study is of a qualitative and explorative nature. The findings exposed in this paper are based on fourteen in-depth semi-structured interviews with Commission officials within DG Employment, Social Affairs and Equal Opportunities, as well as national officials that are/have been members of the Employment Committee (France, Denmark and UK). The interviewees' accounts of their experience in EMCO and within various other processes (Peer Review Programme, bilateral discussions between Member States and Commission et cetera) that operate at the margins of the Employment Committee will be used to decipher the dynamics at play within the European Employment Strategy, and particularly how the Commission has sought further its standing within the institutional framework of the EES. All interviewees were guaranteed anonymity for the purpose of this research. The interviews were recorded and transcribed and all translations from the French to the English language are my own.

2) It should be noted that, for the purpose of this study, the term "Commission" is used as shorthand for the Directorate General (DG) Employment, Social Solidarity and Equal Opportunities.

3) de la Porte and Nanz 2004, Eberlain and Kerwer 2002, Hodson and Maher 2001, Scott and Trubek 2002, Telò 2003, Trubek and Mosher 2003. For an overview of the various strands of academic debate surrounding the EES, see Zeitlin 2005 19-28, Radaelli 2003.

4) For a collection of case studies, see de la Porte and Pochet 2002, Zeitlin 2005. Alongside these comprehensive national case studies of the EES in action, preliminary "thematic studies" are also emerging in the field. For instance, Ravenaud (2001) and Winderton and Foden (2002) evaluate the participation of social partners and local actors in the EES process; likewise, Bisopoulos (2004) and Lefresne (2004) investigate the dynamics of the Peer Review Programme.

5) Numerous case studies extending across a vast array of policy fields, most notably, telecommunications policy (Sandholtz 1993), technology policy (Sandholtz 1992, Peterson 1992), structural policy (Marks 1993), regional policy (Hooghe and Keating 1994), social policy and education (Cram 1993, 1994), but also important integrationist projects such as the SEA (Sandholtz and Zysman 1989) and the EMU (Ross 1995, Jabko 1999), all bear evidence of the Commission acting as a "policy entrepreneur". For an analysis of the Commission's entrepreneurial role during the formative years of the EES (i.e. from the Delors White Paper on "Growth, Competitiveness and Employment" in 1993, to the insertion of the Employment Title in the Amsterdam Treaty in 1997), see Deganis (2006).

6) The impact of the recent streamlining of the BEPGs and the EES remains a matter of dispute. During the course of this study, various conflictual suppositions were voiced by key protagonists in this field. Certain respondents noted the potential risk of a dilution of the EES and its effacement in the face of the growing importance of economic policy objectives; conversely, others underlined the increased visibility of the European Employment Strategy resulting from such an overhaul.

7) The Employment Committee is just one of four recently established Committees associated with the Open Method of Coordination. For a broader analysis of the role of these advisory Committees, see Jacobsson and Vifell 2004 (the other three Committee are, namely, the Economic Policy Committee (EPC), the Economic and Financial Commit- 
tee (EFC) and the Social Protection Committee (SPC)).

8) The Commission, the EMCO Secretariat and the General Secretariat of the Council are also represented within the steering group.

9) EMCO meets approximately six to seven times every year and meetings usually last two days.

10) The Indicators group holds approximately six to seven meetings every year.

11) The Ad-hoc group meets approximately three times every year.

12) Learning among members of the same coalition is considered to be relatively unproblematic (Sabatier and Jenkins-Smith 1993: 48). Thus, attention has focused on identifying the conditions which enable constructive deliberation between members of competing coalitions.

13) The fundamental distinction which emerges from this study between two antagonistic social models has been noted elsewhere by Wincott (2003: 288).

14) It also emerges from this study that a crucial characteristic of both coalitions is their inherently dynamic nature since their membership may fluctuate due to changes in national governments. Respondents repeatedly stressed how Spain switched from the "liberal" to the "social model" coalition following the 2004 general elections. However, certain Member States are invariably identified as being the "flagship" of these advocacy coalitions; most notably, the UK is fundamentally associated with the "liberal" coalition and France and Belgium are consistently identified as being the core members of the "social model" coalition.

15) The composition of both coalitions outlined here remains summary and is based on cursory primary data collected during interviews with members of the Employment Committee. Further research would be needed to determine the exact composition of these coalitions, both with regards to Member States and a variety of other actors (interest group leaders, agency officials, legislators from multiple levels of governments, researchers, journalists, et cetera) which are also said to belong to advocacy coalitions (Sabatier 1998: 103).

\section{6) Rules of Procedure, Paragraph 4, EMCO/001/00/EN}

17) Likewise, on the rare occasions when the process has come to a standstill because of a small minority of intractable national delegates, the principle of "consensus formation" has been advantageously utilized as a means of overcoming such an impasse. Commenting on a the occurrence of a deliberative impasse within the Indicators group, a French official notes: "he (the President of the Indicators group) managed to talk the other Member States into accepting the proposal by saying "you are not going to block the process and go against the consensus ", and so the minority accepted to go along with it".

18) This point has also been raised by Jacobsson and Vifell (2004)

19) Since 1 st January 2006, M. Van der Pas holds the position of Director General of DG Employment, Social Affairs and Equal Opportunities. All interviews informing this study's findings were conducted prior to M. Van der Pass taking office.

20) The Employment Committee's "dual chairmanship" fits squarely with the ACF since Sabatier does not suggest any restriction on the number of policy-brokers operating within a single policy subsystem. Commenting on this state of affairs, a senior Commission official within DG Employment notes, "depending on how forceful the Chair is, the Commission can play a sort of de facto role of Chair if the Chair is not particularly assertive. If the Chair is assertive then the Commission [...] together with the Chair would try to resolve issues. So, the role of the Commission is sometimes co-chair and sometimes more behind the scenes".

21 Commenting on the role of the Secretariat, one member of the Committee notes, "They are the keepers of the text. Everything in Brussels is about the piece of paper; it is not about policy, strategy or truth, it is about who can and who cannot agree with a piece of paper. So the people who draft the paper have a very important role".

22) In practice, once draft opinions have effectively been formulated they are presented to the Employment Committee - assembled in a plenary session - for approval. However, the short delay provided to national officials (preparatory papers and draft opinions are usually sent out 3-4 days prior to EMCO meetings) does not allow Member States to carry out a comprehensive review of the draft opinions, rather, this task is entrusted to the Chairperson who is charged with guaranteeing the validity and accuracy of these documents.

23) As a British official notes, "What we stress as important, the Commission will leave off the list of things worth following up. It is classic chairmanship strategies. [The Commission] will use every trick in the book".

24) As one national official notes, "The Commission behaves in EMCO the same way that it does in a Council working group. In a Council working group, the Commission initiates and then Member States have to convince the Commission to change the proposal. The Commission works in the same way in EMCO".

25) Several national representatives within EMCO underlined the Commission's informational advantage flowing from it central position within the EES. As a French officials notes, "very often Member States do no have complete knowledge of all the process and contextual aspects to the extent that the Commission has"

26) An organization chart detailing the various directorates of the DG Employment, Social Affairs and Equal Opportunities is available on the Europa website: http://ec.europa.eu/dgs/employment_social/staffgui/org_en.pdf

27) For a more detailed account of the use of benchmarking within the OMC, see Arrowsmith et al 2003, Pochet et al: 2001. 
28) Quoted in Van Riel and Van der Meer (2002: 10), Letter by Minister of the Second Chamber of the Dutch Parliament in 13-11-1998, TK, 1998-9, 21501-18, no. 89. p.3.

29) The EES has been acclaimed as a means of establishing a common European employment initiative without having to forge a single template of European capitalism since discourse is fashioned in a seemingly technical language that evades any form of politicisation (Radaelli 2003: 20).

\section{References}

Arrowsmith, J. and Sisson, K. and Marginson, P, (2004) "What can benchmarking offer the OMC?", Journal of European Public Policy, 11 (2) 31 1-328.

Bisopoulos, A. (2003), "The European Employment Strategy: Innovative Governance by Peer Review" in K. Holzinger, C. Knill, D. Lehmkuhl (eds), "Conditions and Patterns of Governance in Historical Comparison", (Opladen: Leske and Budrich).

Borrás, S. and Jacobsson K. (2004), "The Open Method of Coordination and new governance patterns in the EU", Journal of European Public Policy 11(2): 185-208.

Cram, L. (1993), "Calling the Tune Without Paying the Piper? Social Policy Regulation: The Role of the Commission in European Community Social Policy", Policy and Politics, 21(2): 135-46.

Cram, L. (1994), "The European Commission as a multi-organization: social policy and IT policy in the EU", Journal of European Public Policy 1(2): 195-217

de la Porte, C. and Nanz, P. (2004) "The OMC - a deliberative-democratic mode of governance? The cases of employment and pensions", Journal of European Public Policy $11(2)$ : 167-288.

de la Porte, C., Pochet P. (2002), "Building Social Europe through the Open Method of Coordination", (Brussels: PIE-Peter Lang).

de la Porte, C., Pochet, P. (2003), "A Twofold Assessment of Employment Policy Coordination in light of Economic Policy Coordination", in D. Foden and L. Magnussen (eds), "Five Years' Experience of the Luxembourg Employment Strategy", pp13-68, (Brussels: European Trade Union Institute).

de la Porte, C., Pochet P. (2004), "The European Employment Strategy: Existing Research and Remaining Questions", in Journal of European Social Studies 14(1).

Deganis, I. (2006), "Umpire or Norm Entrepreneur? The Commission's Role in the European Employment Strategy", MPhil thesis submitted at Oxford University, April 2006.

Dehousse, R. (2002), "The Open Method of Coordination: A New Policy Paradigm?", Paper presented at the First Pan-European Conference on European Union Politics, "The Politics of European Integration: Academic Acquis and Future Challenges", Bordeaux, 26-28 September. 
Eberlein, B., Kerwer D. (2002), "Theorising the New Modes of European Union Governance", European Integration online Papers (EioP), vol. 6, no. 5.

Ferrera, M. (2001), "The European Social Model between "Hard" Constraints and "Soft" Co-ordination", unpublished paper presented to the "Social Models and EMU: Convergence? Co-existence? The Role of Economic and Social Actors", Economic and Social Committee, Brussels, 19 November 2001.

Franchino, F. (2000), "The Commission's Executive Discretion, Information and Comitology", Journal of Theoretical Politics 12(2): 155-181.

Goetschy, J. (1999), "The European Employment Strategy: Genesis and Development", European Journal of Industrial Relations 5(2): 117-37.

Hodson, D and Maher, I. (2001), "The Open Method as a new mode of governance: The case of soft economic policy co-ordination", in Journal of Common Market Studies, 39(4): 719746.

Hooghe L and Keating M. (1994), "The politics of European Union regional policy", Journal of European Public Policy 1(3): 367-93.

Jabko N. (1999), "In the Name of the Market: How the European Commission paved the way for the Monetary Union", Journal of European Public Policy 6(3): 475-95.

Jabko, N. (2004), "Les critères de Maastricht, préhistoire de la MOC", in R. Dehousse (eds), "L’Europe sans Bruxelles?", (Paris: L’Harmattan).

Jacobsson, K., Vifell, A. (2004) "Towards Deliberative Supranationalism? Analysing the Role of Committees in Soft Co-ordination." Paper presented at the Govencor Final Review Meeting, Brussels, 16-17 February, to be published in Economic Governance in the EU, ed. Linsenmann, Meyer and Wessels (Palgrave Macmillan).

Jobelius S. (2003), "Who Formulates the European Employment Guidelines? The OMC between deliberation and power games", Paper presented to the Annual Conference of the ESPAnet, "Changing European Societies - The role of Social Policy", 13-15th November 2003, Copenhagen.

Kendall, J. (2001), "The third sector and the development of European public policy: Frameworks for analysis", Civil Society Working Paper 19.

Lefresne F. (2004), "Les Peer Reviews: regards croisés sur les mises en œuvre nationales de la Stratégie européenne pour l'emploi", paper prepared for the conference "Gourvernance et expertise de l'emploi en Europe", 13-14 December, Paris.

Levy, R. (2000) [1997], "Managing the Managers: The Commission's Role in the Implementation of Spending Programmes", in N. Nugent (eds), "At the Heart of Union. Studies of the European Commission", (Basingstoke: Macmillan Press), pp206-29. 
Majone G. (1991), "Cross-National Sources of Regulatory Policy-making in Europe and the United States", Journal of Public Policy, 11(1): 76-106.

Marks, G. (1993), "Structural Policy and Multilevel Governance in the EC", in A. Cafruny and G. Rosenthal (eds), "The State of the European Community. Volume 2: The Maastricht Debates and Beyond", (Boulder, Colo.: Lynne Rienner), pp391-410.

Mendrinou, M. (1996), "Non-compliance and the European Commission's Role in Integration", Journal of European Public Policy, 3(1): 1-22.

Nugent N (2000) [1997], "At the Heart of the Union" in N. Nugent (eds), "At the Heart of the Union - Studies of the European Commission", Introduction, (Basingstoke: Macmillan Press) ppl-27.

Parrish, R. (2003), "The politics of sports regulation in the European Union", Journal of European Public Policy, 10(2): 246-262.

Peters B.G. (1992), "Bureaucratic Politics and the Institutions of the European Community", in A. Sbragia (eds)(1992), "Euro-Politics: Institutions and Policymaking in the "New" European Community", (Washington: The Brookings Institution), pp75-122.

Peters B. G. (2000)[1997], "The Commission and Implementation in the European Union: Is There an Implementation Deficit and Why?", in N. Nugent (eds), "At the Heart of Union. Studies of the European Commission", Macmillan Press, pp190-205.

Peterson, J. (1992), "The European Technology Community: Policy Networks in a Supranational Setting", in D. Marsh and R.A.W. Rhodes (eds), "Policy Networks in British Government", (Oxford: Clarendon Press), pp226-48.

Pierson, P. (1996), "The Path to European Integration: A Historical Institutionalist Analysis", Comparative Political Studies, 29(2): 123-63.

Pochet, P., de la Porte C., Room G., (2001), "Social Benchmarking, policy making and new governance in the EU", in Journal of European Social Policy 11: 291-307.

Pollack, M.A. (1994), "Creeping Competence: The Expanding Agenda of the European Community", Journal of Public Policy, 14(2): 95-145.

Pollack, M.A. (1997), "Delegation, agency, and agenda setting in the European Community", in International Organization 51(1).

Radaelli C.M. (1999), "Harmful Tax Competition in the EU: Policy Narratives and Advocacy Coalitions", Journal of Common Market Studies 37(4): 661-82.

Radaelli C. M. (2003), "The Open Method of Coordination: A new governance architecture for the European Union?", SIEPS report nrl, Stockholm: Swedish Institute for European Policy Studies. 
Raveaud, G. (2001), "La dimension Européenne des politiques d'emploi françaises. Une analyse de la participation des partenaires sociaux à l'élaboration du PNAE 2001", Rapport pour la Délégation Générale à l'Emploi et à la Formation Professionnelle (DGEFP), ministère de l'emploi et de la Solidarité, Paris November 2001.

Rhinard, M. (2002), "Ideas, Interests and Policy Change in the European Union. The Mobilization of Frames by Actors in the Agricultural and Biotechnology Sectors", dissertation submitted for the degree of Doctor of Philosophy at the University of Cambridge.

Ross G. (1995), "Jacques Delors and European Integration", (New York: Oxford UP)

Sabatier P. (1998), "The Advocacy Coalition Framework: Revisions and Relevance for Europe", Journal of European Public Policy 5(1), pp98-130.

Sabatier P. and Jenkins-Smith H. (eds) (1993), "Policy change and Learning: An Advocacy Coalition Approach", (Boulder, CO: Westview Press).

Sabatier P and Jenkins-Smith H. (1999), "The advocacy coalition framework: an assessment', in P.A. Sabatier (eds), "Theories of Policy Process", (Boulder, CO: Westview Press), pp 1 17-66.

Sabatier, P. and Zafonte M (1997), "Policy orientated learning between coalitions: characteristics of successful professional/scientific fora", Paper presented at the AAAS Meetings, Seattle, 9 February.

Sandholtz, W. (1992), "ESPRIT and the Politics of International Collective Action", in Journal of Common Market Studies, 30(1): 1-21.

Sandholtz W. (1993), "Institutions and Collective Action: The New Telecommunications in Western Europe", World Politics, 45(2): 242-70.

Sandholtz, W. and Zysman, J. (1989), "1992: Recasting the European Bargain", World Politics, 42(1): 95-128.

Schmidt, V. A. (2000), "Values and Discourse in the Politics of Welfare State Adjustment", in F.W. Scharpf and V.A. Schmidt (eds), "Welfare and Work in the Open Economy. Vol. 1: From Vulnerability to Competitiveness", (Oxford: Oxford UP).

Scott J. and Trubek D.M. (2002), "Mind the gap: law and new approaches to governance in the European Union", European Law Journal 8(1): 1-18

Scott, W.R. (1987), "Organizations: Rational Natural and Open Systems", (Ebglewood Cliffs, N.J.: Prentice-Hall).

Telò, M. (2003), "Governance and government in the European Union: The open method of coordination", in Rodrigues, M. J. (eds), "The Knowledge Economy in Europe. A Strategy for International Competitiveness and Social Cohesion", (Cheltenham: Edward Elgar). 
Thedvall, R. (2006), "Eurocrats at Work. Negotiating Transparency in Postnational Employment Policy", Stockholm Studies in Social Anthropology, 58. (Stockholm: Almqvist \& Wiksell International).

Trubek D.M. and Mosher J. (2003), "New Governance, Employment Policy, and the European Social Model", in Zeitlin, J. and Trubek D.M. (eds), "Governing Work and Welfare in a New Economy: European and American Perspectives", (Oxford: Oxford UP), pp33-58.

Van Riel, B. and van der Meer, M. (2002), "The advocacy coalition for European employment policy: The European integration process after EMU", in Hegmann, H. and Neumärker, B. (eds.), "Die Europäische Union aus politökonomischer Perspective", (Metropolis Verlag), pp.309-328.

Vandenbrouke, F. (2002), "Foreword: Sustainable Social Justice and "Open Co-ordination" in Europe", in Esping-Andersen G., Gallie D., Hemerijck A., and Myles J. (eds), "Why We Need a New Welfare State", (Oxford: Oxford UP), pp.viii-xxiv.

Weber, N. and Christophersen T. (2002), "The influence of non-governmental organizations on the creation of Natura 2000 during the European policy process", Forest Policy and Economics, 4(1): 1-12.

Wincott, D. (2003), "The idea of the European social model: limits and paradoxes of Europeanisation", in K. Featherstone and C.M. Radaelli (eds), "The Politics of Europeanisation", (Oxford: Oxford UP).

Winderton, J. and Foden D. (2002), "The Trade Unions, the Luxembourg Process in the elaboration of the European Employment strategy", paper presented at the UACES Workshop, Loughborough University, 26 April 2002.

Zeitlin, J and Pochet, P. (2005), "The Open Method of Coordination in Action - The European Employment and Social Inclusion Strategies", (Brussels: P.I.E. - Peter Lang).

Zito, A. R. (2001), "Epistemic Communities, collective entrepreneurship and European integration", in Journal of European Public Policy, 8(4): 585-60. 